\title{
Pulmonary function in scleroderma
}

\author{
B L A I R R I TCHIE ${ }^{1}$
}

From the University of Melbourne Department of Medicine, Royal Melbourne Hospital

Pulmonary manifestations of scleroderma have been well documented in terms of the clinical, radiological, and pathological appearances (Orabona and Albano, 1958). The variability of the disease is indicated by case reports of respiratory manifestations without evidence of radiological abnormalities in the lung fields (Miller, Fowler, and Helmholtz, 1959a), the presence of radiological abnormalities without symptoms (Orabona and Albano, 1958), pulmonary manifestations preceding the cutaneous and articular changes (Hayman and Hunt, 1952 ; Shuford, Seaman, and Goldman, 1953), and pathological changes without clinical evidence (Piper and Helwig, 1955).

A more objective assessment of the pulmonary changes, and their earlier detection even in the absence of radiological changes, is possible by means of tests of pulmonary function. Although, until recently, such studies have been infrequent, the pattern of abnormality of a reduced ventilatory capacity, a reduction in lung volumes, and evidence of 'alveolar-capillary block' was recorded by Baldwin, Cournand, and Richards (1949) and by Spain and Thomas (1950), while Miller et al. (1959a) reported abnormalities of lung function in the absence of radiological changes.

This paper reports more extensive studies of pulmonary function in 22 patients with scleroderma and correlates these findings with the clinical, radiological, electrocardiographic, and pathological findings. Particular attention is paid to the relation of the pulmonary findings to the extent of the skin changes. Evidence is presented to support the view that scleroderma is essentially a generalized disease, the extent of the visceral involvement being unrelated to the extent of the cutaneous manifestations.

\section{MATERIAL AND METHODS}

Twenty-two patients with scleroderma were studied, 17 females (aged 25 to 75 , mean 51.2 years) and five males (aged 38 to 61, mean 46.4 years). Eighteen patients had been investigated previously as part of a larger study of the extra-pulmonary manifestations

\footnotetext{
1 Present address: King's College Hospital, London, S.E.5.
}

of scleroderma (Lumb, F., to be published); the four others were referred from out-patient clinics for lung $\vec{x}$ function tests. Raynaud's phenomenon, stiffness of the fingers, or joint pains had been present for two to 36 years (mean 10.2 years). Symptoms had been present for over 10 years in six patients. All patients had characteristic skin changes, which were localized to the fingers in eight but were more extensive in the remainder; 15 patients had radiological or biochemical evidence of gastro-intestinal involvement.

CLINICAL ASSESSMENT In the assessment of the symptoms and signs of cardiac and pulmonary $\vec{\varphi}$ disease, special attention was paid to the definition of $\stackrel{\nexists}{\perp}$ exertional dyspnoea, changes in the skin of the thorax, thoracic mobility, and adventitious sounds. Respiratory symptoms were assessed by the use of a questionnaire (Fletcher and Tinker, 1961). Chronic bronchitis is defined as the presence of cough or sputum for more than three months of the year.

Exercise tolerance was classified as follows: Grade $\overrightarrow{\vec{B}}$ 1: able to keep up with others of the same age on stairs, hills, or heavy work ; Grade 2: able to keep up with others of the same age on the flat only; Grade 3: unable to keep up on the flat but able to walk for a mile at own pace ; Grade 4: able to walk a few yards only without resting; and Grade 5: unable to walk more than 25 yards on the flat, breathless on dressing, or confined to the house by dyspnøea.

The presence and extent of increased thickness and loss of elasticity of the skin over the chest wall were $\delta$ determined by inspection and palpation. The chest expansion from full expiration to full inspiration was 0 measured at the level of the third costal cartilage, the highest of three readings being accepted. Persistent $\frac{7}{2}$ pulmonary crepitations on deep inspiration, especially at the bases, were carefully sought by two observers $N$ independently.

Postero-anterior and lateral chest radiographs were $N$ read independently by three observers who were unaware of the clinical findings. In particular, they were $\sigma$ asked to record appearances suggestive of cystic or fibrotic changes in the lung parenchyma; the recorded $\frac{0}{\subset}$ results reflect the combined judgments. A standard 12-䨋 lead electrocardiogram was recorded on each patient. In all cases a barium swallow examination was per- $T$ formed to assess the motility and diameter of the oesophagus.

PULMONARY FUNCTION STUDIES With the patient seated, vital capacity (V.C.), estimated in the conven- 
tional unhurried manner, and a forced expiratory spirogram were recorded using a low resistance spirometer and Palmer kymograph with a paper speed of $3 \mathrm{~cm}$./sec. both before and after one and a half minutes' inhalation of a $1 \%$ isoprenaline sulphate aerosol from a Wright nebulizer with compressed air. Normal standards for V.C. and forced expiratory volume in 1 second (F.E.V.1.0) were taken from Miller, Johnson, and Wu (1959b). Lung volumes were measured by the closed-circuit helium dilution method and compared with the predicted values by the formulae of Needham, Rogan, and McDonald (1954). Total lung capacity (T.L.C.) was predicted from the simple regression based on height ; $6 \%$ was added to predicted values to convert from ambient to body temperature (atmospheric pressure, water vapour saturation). Ventilatory response to exercise at a predetermined work level was measured in 19 patients during a five-minute stepping test previously described with normal standards $(29 \pm 5 \mathrm{l} / \mathrm{min}$.) from this laboratory (Gandevia, 1962). The result is expressed as a standardized ventilation in litres per minute 'adjusted' to a $300 \mathrm{~kg}$. M. per minute work level (S.V.300). The work levels used were adjusted according to sex and stated exercise tolerance; unless exercise tolerance was severely impaired, a $350 \mathrm{~kg}$. M. level was used for males and a $250 \mathrm{~kg}$. M. level for females. The diffusing capacity of the lungs for carbon monoxide $\left(\mathrm{D}_{\mathrm{Lco}}\right)$ was determined in 18 patients by the single-breath method of Ogilvie, Forster, Blakemore, and Morton (1957). The mean of duplicate estimations, which agreed to within $\pm 2 \mathrm{ml}$, was accepted. Lung compliance, using a thin-walled oesophageal balloon $11 \mathrm{~cm}$. long containing $2 \mathrm{ml}$. of air, was measured in 19 patients during spontaneous breathing in the sitting position at respiratory rates between 8 and $20 / \mathrm{min}$, and during a slow vital capacity manoeuvre with breath-holding in the more co-opera- tive subjects. The pressure difference between the mouth and the oesophagus and the tidal volumes were recorded as a pressure-volume 'loop' with the Godart compliance apparatus. The results of $D_{L c s}$ and compliance were compared with those obtained by the same methods in 20 normal subjects of the same age and sex distribution as the patients with scleroderma ; the lowest limits of normal values for these are 14 $\mathrm{ml} . / \mathrm{min} . / \mathrm{mm}$. $\mathrm{Hg}$ and 0.100 litre $/ \mathrm{cm}$. water respectively. The control subjects had no respiratory symptoms or signs, a normal chest radiograph, and normal values for V.C. and F.E.V.1.0.

\section{RESULTS}

CLINICAL ASSESSMENT Table I shows the physical characteristics and symptoms in the 22 patients studied. Thirteen patients had some impairment of exercise tolerance. Ten gave a history of chronic bronchitis; only four of these patients smoked (Nos. 3, 9, 10, and 20) and in five of the nonsmokers bronchitic symptoms developed after the onset of symptoms of scleroderma. Three patients (Nos. 10, 16, and 21) had a history of pleurisy which began after the onset of symptoms of scleroderma.

Table II shows the results of the clinical, radiographic, and electrocardiographic examination. The skin over the chest wall was involved in seven patients but lesions extended below the upper onethird of the chest in only one patient (No. 7). Twelve patients had a chest expansion of less than $5 \mathrm{~cm}$. ; nine of these had no changes in the skin of the chest wall. Crepitations were present in 14 subjects but were localized to one side in four.

T ABLE I

PHYSICAL CHARACTERISTICS AND SYMPTOMS

\begin{tabular}{|c|c|c|c|c|c|c|c|c|}
\hline $\begin{array}{c}\text { Patient } \\
\text { No. }\end{array}$ & Sex & Age & $\begin{array}{c}\text { Height } \\
\text { (cm.) }\end{array}$ & $\begin{array}{l}\text { Weight } \\
\text { (kg.) }\end{array}$ & $\begin{array}{c}\text { Duration of } \\
\text { Symptoms of } \\
\text { Scleroderma } \\
\text { (Years) }\end{array}$ & Respiratory Symptoms & $\begin{array}{c}\text { Exercise } \\
\text { Tolerance } \\
\text { Grade }\end{array}$ & $\begin{array}{l}\text { Smoking } \\
\text { History }\end{array}$ \\
\hline $\begin{array}{l}1 \\
2 \\
3 \\
4 \\
5 \\
6 \\
7 \\
8 \\
9 \\
10 \\
11 \\
12 \\
13 \\
14 \\
15 \\
16 \\
17 \\
18 \\
19 \\
20 \\
21 \\
22\end{array}$ & $\begin{array}{c}\mathbf{F} \\
\mathbf{F} \\
\mathbf{M} \\
\mathbf{F} \\
\mathbf{F} \\
\mathbf{M} \\
\mathbf{M} \\
\mathbf{F} \\
\mathbf{M} \\
\mathbf{F} \\
\mathbf{F} \\
\mathbf{F} \\
\mathbf{F} \\
\mathbf{F} \\
\mathbf{F} \\
\mathbf{F} \\
\mathbf{F} \\
\mathbf{F} \\
\mathbf{F} \\
\mathbf{M} \\
\mathbf{F} \\
\mathbf{F}\end{array}$ & $\begin{array}{l}37 \\
45 \\
44 \\
47 \\
67 \\
61 \\
42 \\
64 \\
38 \\
51 \\
52 \\
73 \\
49 \\
58 \\
58 \\
35 \\
25 \\
69 \\
75 \\
47 \\
34 \\
31\end{array}$ & $\begin{array}{l}162.5 \\
165.0 \\
169.5 \\
167.0 \\
157.5 \\
180.0 \\
180.0 \\
162.5 \\
175.0 \\
167.0 \\
167.0 \\
157.5 \\
147.0 \\
165.0 \\
157.5 \\
152.0 \\
157.5 \\
162.5 \\
167.0 \\
175.0 \\
157.5 \\
160.0\end{array}$ & $\begin{array}{l}51 \cdot 0 \\
56 \cdot 5 \\
71 \cdot 5 \\
56 \cdot 5 \\
55 \cdot 0 \\
57 \cdot 5 \\
72 \cdot 5 \\
40 \cdot 5 \\
66 \cdot 5 \\
58 \cdot 5 \\
62.0 \\
42 \cdot 0 \\
35 \cdot 5 \\
65.0 \\
54 \cdot 5 \\
48 \cdot 0 \\
60.0 \\
77.0 \\
54 \cdot 0 \\
76.0 \\
51.0 \\
47.0\end{array}$ & $\begin{array}{r}4 \\
6 \\
3 \\
24 \\
30 \\
7 \\
4 \\
2 \\
8 \\
18 \\
4 \\
7 \\
36 \\
14 \\
8 \\
19 \\
6 \\
4 \\
9 \\
3 \\
5 \\
4\end{array}$ & $\begin{array}{l}\text { Nil } \\
\text { Nil } \\
\text { Bronchitis } 5 \text { years } \\
\text { Bronchitis } 5 \text { years } \\
\text { Bronchitis } 2 \text { years } \\
\text { Nil } \\
\text { Nil } \\
\text { Bronchitis many years } \\
\text { Bronchitis } 12 \text { years } \\
\text { Bronchitis } 30 \text { years; pleurisy } 12 \text { years previously } \\
\text { Nil } \\
\text { Bronchitis } 1 \text { year } \\
\text { Bronchitis } 2 \text { years } \\
\text { Nil } \\
\text { Nil } \\
\text { Pleurisy } 3 \text { months previously } \\
\text { Nil } \\
\text { Bronchitis } 5 \text { years } \\
\text { Nil } \\
\text { Bronchitis } 10 \text { years } \\
\text { Pleurisy } 4 \text { years previously } \\
\text { Nil }\end{array}$ & $\begin{array}{r}2 \\
2 \\
1 \\
1 \\
3 \\
4 \\
1 \\
2 \\
1 \\
1 \\
1 \\
4 \\
4 \\
1 \\
1 \\
3 \\
1 \\
1 \\
3-4 \\
4 \\
4 \\
2-4 \\
4-5\end{array}$ & 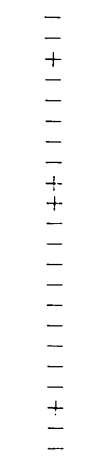 \\
\hline
\end{tabular}


T A B LE II

RESULTS OF CLINICAL, RADIOGRAPHIC, AND E.C.G. EXAMINATIONS

\begin{tabular}{|c|c|c|c|c|c|c|c|c|c|}
\hline \multirow{2}{*}{$\begin{array}{c}\text { Patient } \\
\text { No. }\end{array}$} & \multicolumn{3}{|c|}{ Skin Changes } & \multirow{2}{*}{$\begin{array}{c}\text { Chest } \\
\text { Expansion } \\
\text { (cm.) }\end{array}$} & \multirow{2}{*}{$\begin{array}{c}\text { Pulmonary } \\
\text { Crepita- } \\
\text { tions }^{1}\end{array}$} & \multirow{2}{*}{$\begin{array}{c}\text { Chest } \\
\text { Radiograph }\end{array}$} & \multirow{2}{*}{$\begin{array}{c}\text { Blood } \\
\text { Pressure } \\
(\mathrm{mm} . \mathrm{Hg})\end{array}$} & \multirow{2}{*}{ E.C.G. } & \multirow{2}{*}{$\underset{\text { Swallow }}{\text { Barium }}$} \\
\hline & $\underset{\text { Only }}{\text { Hands }}$ & $\begin{array}{l}\text { Chest } \\
\text { Wall }\end{array}$ & $\begin{array}{l}\text { Other } \\
\text { Sites }\end{array}$ & & & & & & \\
\hline $\begin{array}{r}1 \\
2 \\
3 \\
4 \\
5 \\
6 \\
7 \\
8 \\
9 \\
10 \\
11 \\
12 \\
13\end{array}$ & $\begin{array}{l}- \\
\overline{+} \\
\overline{+} \\
\overline{-} \\
- \\
\overline{+} \\
+ \\
-\end{array}$ & $\begin{array}{l}+ \\
+ \\
+ \\
+ \\
+ \\
+ \\
+ \\
- \\
- \\
-\end{array}$ & $\begin{array}{l}+ \\
+ \\
+ \\
+ \\
+ \\
+ \\
+ \\
+ \\
+ \\
+\end{array}$ & $\begin{array}{r}6 \cdot 5 \\
4 \cdot 0 \\
10 \cdot 0 \\
4 \cdot 0 \\
2 \cdot 0 \\
5 \cdot 0 \\
7 \cdot 0 \\
5 \cdot 0 \\
4 \cdot 5 \\
5 \cdot 5 \\
7 \cdot 5 \\
3 \cdot 5 \\
4 \cdot 0\end{array}$ & $\begin{array}{l}- \\
++ \\
+ \\
++ \\
+ \\
+ \\
- \\
++ \\
+ \\
+\end{array}$ & $\begin{array}{l}\text { Normal } \\
\text { Normal } \\
\text { Normal } \\
\text { Normal } \\
\text { Normal } \\
\text { Increased heart size } \\
\text { Normal } \\
\text { Normal } \\
\text { Normal } \\
\text { Normal } \\
\text { Normal } \\
\text { Normal } \\
\text { Bilateral basal reticular and }\end{array}$ & $\begin{array}{l}120 / 70 \\
140 / 90 \\
120 / 75 \\
140 / 90 \\
160 / 90 \\
130 / 80 \\
180 / 105 \\
120 / 65 \\
210 / 130 \\
110 / 50 \\
130 / 80 \\
120 / 65 \\
165 / 90\end{array}$ & $\begin{array}{l}\text { Normal } \\
\text { Normal } \\
\text { Normal } \\
\text { Normal } \\
\text { Normal } \\
\text { Right bundle branch block } \\
\text { Normal } \\
\text { Normal } \\
\text { Normal } \\
\text { Normal } \\
\text { Transient T wave inversion } V_{1-3} \\
\text { Normal } \\
\text { Normal }\end{array}$ & $\begin{array}{l}- \\
++ \\
- \\
++ \\
\overline{+} \\
+ \\
+ \\
++ \\
+ \\
+ \\
+ \\
++\end{array}$ \\
\hline $\begin{array}{l}14 \\
15 \\
16 \\
17 \\
18 \\
19\end{array}$ & $\begin{array}{l}- \\
+ \\
+ \\
- \\
-\end{array}$ & $\begin{array}{l}- \\
\overline{-} \\
\overline{+} \\
-\end{array}$ & $\begin{array}{l}+ \\
\overline{-} \\
+ \\
+ \\
+\end{array}$ & $\begin{array}{l}3 \cdot 5 \\
5 \cdot 5 \\
8 \cdot 0 \\
2 \cdot 0 \\
1 \cdot 0 \\
4 \cdot 0\end{array}$ & $\begin{array}{l}- \\
+ \\
+ \\
++ \\
++\end{array}$ & $\begin{array}{l}\text { Normal } \\
\text { Normal } \\
\text { Cysts right base } \\
\text { Normal } \\
\text { Normal } \\
\text { Bilateral fine reticular and } \\
\text { nodular shadows over } \\
\text { lower half of lung fields }\end{array}$ & $\begin{array}{l}160 / 100 \\
160: 90 \\
130 / 90 \\
100 / 70 \\
130 / 80 \\
220: 110\end{array}$ & $\begin{array}{l}\text { Normal } \\
\text { Normal } \\
\text { Normal } \\
\text { Normal } \\
\text { Normal } \\
\text { Right bundle branch block }\end{array}$ & $\begin{array}{l} \pm \\
- \\
- \\
\pm \\
-\end{array}$ \\
\hline 20 & + & - & - & $6 \cdot 0$ & +++ & $\begin{array}{l}\text { Bilateral coarse reticulation } \\
\text { over lower two-thirds of } \\
\text { lung fields }\end{array}$ & 110.90 & R.ight ventricular hypertrophy & ++ \\
\hline 21 & + & - & - & $4 \cdot 0$ & +++ & $\begin{array}{l}\text { Bilateral basal coarse reti- } \\
\text { culation }\end{array}$ & 105,75 & Right ventricular hypertrophy & ++ \\
\hline 22 & - & - & + & $4 \cdot 0$ & $+t+$ & $\begin{array}{l}\text { Increased basal broncho- } \\
\text { vascular markings; dilated } \\
\text { main pulmonary artery }\end{array}$ & $180 ' 80$ & Right ventricular hypertrophy & - \\
\hline
\end{tabular}

+ Localized to one side; ++ at both bases; +++ extending above inferior angle of scapula ulceration of oesophagus.

Radiological abnormalities in the lung parenchyma attributable to scleroderma were present in six subjects. Two patients (Nos. 20 and 21) showed a coarse reticular pattern which extended over the lower two-thirds of the lung fields in one (No. 20, Fig. 1). Two (Nos. 13 and 19) showed combined reticular and nodular shadows at the bases. One subject (No. 22, Fig. 2) showed marked dilatation of the pulmonary artery with a minimal increase in the basal broncho-vascular markings, and another (No. 16) showed large 'emphysematous' cysts at the right base. With one exception (No. 17), all patients with radiological changes had basal crepitations, but three patients with basal crepitations had a normal chest radiograph. Radiological abnormalities in the lungs were present in three patients who had no respiratory symptoms. Four patients had casual blood pressure recordings above $160 / 90 \mathrm{~mm}$. Hg without clinical or electrocardiographic evidence of left ventricular hypertrophy or retinal changes; basal crepitations were present in two of these (Nos. 9 and 19), and one (No. 19) had a radiographic abnormality. Radiological evidence of cardiac enlargement was present in two other patients (Nos. 6 and 11); in one (No. 11) this was a transient finding a year before the present study.
Electrocardiographic abnormalities were present in five patients, two having right bundle branch block (Nos. 6 and 19), three right ventricular hypertrophy (Nos. 20,21, and 22), and a sixth (No. 11) one year previously had temporary $T$ wave inversion over leads $V_{1-3}$ which was not present at the time of the study. Four of these patients (Nos. 19, 20, 21, and 22) had radiological abnormalities in the lung fields and five (Nos. 6, $19,20,21$, and 22) had basal crepitations. The presence of pulmonary hypertension was confirmed in one patient (No. 22) by right heart catheterization, the main pulmonary artery pres- $\frac{7}{0}$ sure being $65 \mathrm{~mm}$. $\mathrm{Hg}$ systolic and $30 \mathrm{~mm}$. $\mathrm{Hg}$ diastolic.

The barium swallow examination was abnormal $N$ in 13 patients. Two patients (Nos. 6 and 13) had gross stasis with dilatation and ulceration of the $\omega$ oesophageal mucosa. Nine of these patients had normal lungs radiologically.

PULMONARY FUNCTION Table III shows the results? of the pulmonary function studies expressed in 0 absolute values. All but one of the 22 patients $\mathbb{\mathbb { D }}$ tested showed some abnormality; the exception $\frac{\rho}{\Phi}$ (No. 16) was not fully studied. Seven patients 0 showed single defects in pulmonary function, four 


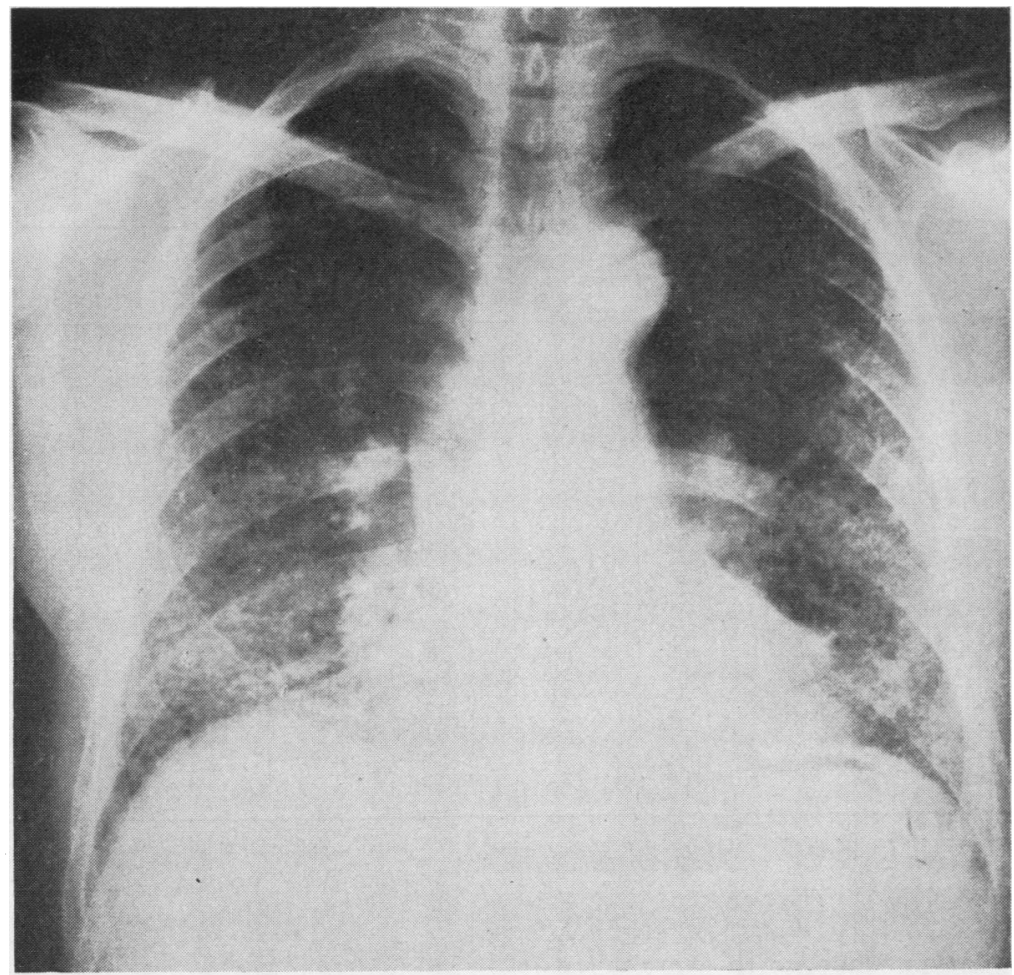

FIG. 1. Patient 20. Chest radiograph showing reticular and nodular shadows over lower two-thirds of lung fields.

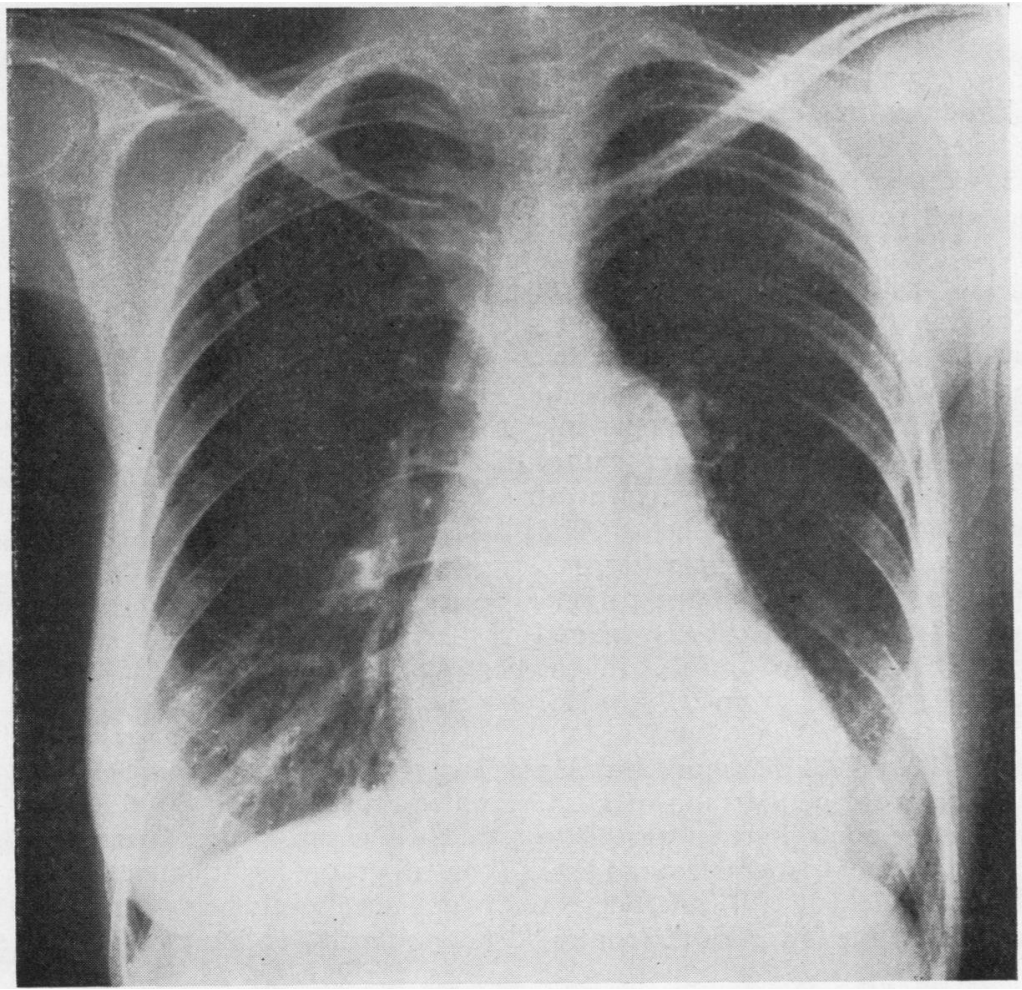

FIG. 2. Patient 22. Chest radiograph showing dilated main pulmonary artery with some increase in the basal broncho-vascular markings. 
TA B LE III

PULMONARY FUNCTION STUDIES

\begin{tabular}{|c|c|c|c|c|c|c|c|c|c|c|c|}
\hline $\begin{array}{c}\text { Patient } \\
\text { No. }\end{array}$ & $\begin{array}{c}\text { Vital } \\
\text { Capacity } 1 \\
\text { (1.) }\end{array}$ & F.E.V.1.0 & $\frac{\text { F.E.V.1.0 }}{\text { V.C. }}$ & $\underset{\text { (l.) }}{\text { T. L.C. }}{ }^{1}$ & $\frac{\text { R.V. }(\%)^{2}}{\text { T.L.C. }}$ & $\frac{\text { F.R.C. }(\%)}{\text { T.L.C. }}$ & $\begin{array}{c}\text { S.V.300 } \\
\text { (1./ } \min .)\end{array}$ & $\begin{array}{c}\text { Dico } \\
\text { (ml. min. } \\
\mathrm{mm} \cdot \mathrm{Hg})\end{array}$ & $\frac{\text { Dlco }}{\text { B.S.A. }^{3}}$ & $\begin{array}{c}\text { Compliance } \\
(\mathrm{I} . \mathrm{cm} . \\
\left.\mathrm{H}_{2} \mathrm{O}\right)\end{array}$ & $\begin{array}{c}\begin{array}{c}\text { Com- } \\
\text { pliance }\end{array} \\
\text { F.R.C. }\end{array}$ \\
\hline $\begin{array}{l}1 \\
2 \\
3 \\
4 \\
5 \\
6 \\
7 \\
8 \\
9 \\
10 \\
11 \\
12 \\
13 \\
14 \\
15 \\
16 \\
17 \\
18 \\
19 \\
20 \\
21 \\
22\end{array}$ & $\begin{array}{l}3 \cdot 13(89) \\
3 \cdot 17(90) \\
4.99(117) \\
3 \cdot 76(102) \\
2.04(67) \\
4.08(96) \\
4.74(98) \\
2.67(81) \\
4.44(95) \\
2 \cdot 29(63) \\
3.78(104) \\
2.05(68) \\
1.73(56) \\
1.88(54) \\
2.38(77) \\
3.15(105) \\
2.59(78) \\
1.84(56) \\
2.29(71) \\
2.54(58) \\
1.72(72) \\
2 \cdot 10(66)\end{array}$ & $\begin{array}{l}2.49 \\
2.65 \\
4.55 \\
2.96 \\
1.45 \\
3.88 \\
3.41^{4} \\
1.99 \\
3.60 \\
2.04 \\
3.09 \\
1.74 \\
1.47 \\
1.72 \\
1.45 \\
2.50 \\
2.584 \\
1.67 \\
1.93 \\
2.464 \\
1.50 \\
1.60\end{array}$ & $\begin{array}{l}80 \\
88 \\
91 \\
79 \\
70 \\
88 \\
64 \\
78 \\
79 \\
83 \\
79 \\
78 \\
94 \\
87 \\
68 \\
90 \\
90 \\
90 \\
82 \\
85 \\
82 \\
80\end{array}$ & $\begin{array}{l}4.61(98) \\
6.51(134) \\
7.63(118) \\
5.28(100) \\
3.02(67) \\
6.26(87) \\
0.81(95) \\
4.69(99) \\
5.64(83) \\
3.79(76) \\
5.26(105) \\
3.66(90) \\
4.54(87) \\
3.42(71) \\
5.15(115) \\
4.84(108) \\
3.61(80) \\
3.47(74) \\
4.38(88) \\
4.80(70) \\
2.82(63) \\
3.04(66)\end{array}$ & $\begin{array}{l}32(36) \\
51(38) \\
35(34) \\
28(39) \\
33(46) \\
35(48) \\
30(35) \\
43(47) \\
21(34) \\
40(40) \\
28(40) \\
44(50) \\
62(43) \\
45(41) \\
54(43) \\
35(36) \\
28(31) \\
47(43) \\
48(49) \\
47(35) \\
39(36) \\
31(35)\end{array}$ & $\begin{array}{l}58(55) \\
66(55) \\
45(52) \\
49(55) \\
50(59) \\
59(68) \\
63(56) \\
69(64) \\
58(55) \\
60(55) \\
54(53) \\
67(65) \\
77(64) \\
55(53) \\
66(58) \\
59(56) \\
44(50) \\
56(59) \\
61(61) \\
66(52) \\
63(55) \\
61(56)\end{array}$ & $\begin{array}{l}40 \cdot 3 \\
39 \cdot 6 \\
39 \cdot 7 \\
33 \cdot 7 \\
69 \cdot 9 \\
46 \cdot 5 \\
37 \cdot 4 \\
55 \cdot 6 \\
34 \cdot 1 \\
28 \cdot 6 \\
31 \cdot 0 \\
17 \cdot 8 \\
51 \cdot 3 \\
21 \cdot 0 \\
31 \cdot 4 \\
28 \cdot 3 \\
29 \cdot 2 \\
30 \cdot 2 \\
40 \cdot 2 \\
64 \cdot 1 \\
-\end{array}$ & $\begin{array}{r}20 \cdot 2 \\
24 \cdot 5 \\
12 \cdot 4 \\
8 \cdot 3 \\
21 \cdot 5 \\
23 \cdot 1 \\
17 \cdot 5 \\
28 \cdot 7 \\
17 \cdot 3 \\
12 \cdot 8 \\
11 \cdot 2 \\
14 \cdot 3 \\
17 \cdot 3 \\
22 \cdot 4 \\
14 \cdot 6 \\
20 \cdot 5 \\
14 \cdot 7 \\
9 \cdot 0 \\
6 \cdot 3 \\
2 \cdot 3\end{array}$ & $\begin{array}{r}13 \cdot 2 \\
13 \cdot 4 \\
7.6 \\
5 \cdot 4 \\
12 \cdot 1 \\
12 \cdot 0 \\
12 \cdot 5 \\
15.9 \\
10 \cdot 4 \\
7 \cdot 5 \\
8 \cdot 1 \\
11 \cdot 7 \\
10 \cdot 1 \\
14 \cdot 5 \\
9 \cdot 1 \\
11 \cdot 2 \\
9.2 \\
4.7 \\
4.2 \\
1.6\end{array}$ & $\begin{array}{c}0.136 \\
0 . \overline{176} \\
0.214 \\
0.094 \\
0.250 \\
0.300 \\
0.065 \\
0.088 \\
0.094 \\
0.280 \\
0.150 \\
0.074 \\
0.088 \\
0.133 \\
0 . \overline{143} \\
0.086 \\
0.100 \\
0.083 \\
-\end{array}$ & $\begin{array}{c}0.051 \\
0.052 \\
0.084 \\
0.062 \\
0.068 \\
0.070 \\
0.020 \\
0.027 \\
0.041 \\
0.070 \\
0.061 \\
0.021 \\
0.047 \\
0.039 \\
0.089 \\
0.044 \\
0.037 \\
0.026 \\
- \\
-\end{array}$ \\
\hline
\end{tabular}

1 Figures in brackets express result as percentage of predicted value. ${ }^{2}$ Predicted values in trackets. ${ }^{3}$ Body surface area.
Greater than $10 \%$ increase in F.E.V.1.0 after bronchodilator aerosol.

an increased ventilatory response to exercise, two a reduced $D_{L c 3}$, and one a lowered compliance.

In 12 patients the V.C. was reduced below $80 \%$ of the predicted values. The F.E.V. ${ }_{\cdot 1.0}$ was reduced below $70 \%$ of the V.C. in two patients (Nos. 7 and 15), and in three (Nos. 7, 17, and 20) a $10 \%$ increase in F.E.V..$_{1.0}$ was found after bronchodilator aerosol. The total lung capacity was below $80 \%$ of the predicted value in seven subjects, all of whom had a reduced V.C., residual volume (R.V.), and functional residual capacity (F.R.C.). Three others (Nos. 2, 13, and 15) had a significant increase (above $120 \%$ predicted) in F.R.C. and R.V. ; in one (No. 15) there was evidence of airways obstruction. Eleven of the 20 subjects tested had an abnormally high ventilatory response to exercise (above 34 litres $/ \mathrm{min}$.). Three patients (Nos. 12, 16, and 18) showed a normal ventilatory response but complained of severe impairment of exercise tolerance; the very low value of 17.8 litres/min. (No. 12) is probably a technical error.

Figure 3 is a plot of $D_{L c o}$ in 20 of the patients with scleroderma and 20 control subjects paired for age and sex. The range of results in the patients with scleroderma was from $2 \cdot 3$ to 28.7 $\mathrm{ml} . / \mathrm{min} . / \mathrm{mm}$. $\mathrm{Hg}$ (mean $16.0 \pm 6.6$ ) and in the control group from 14.0 to $27.8 \mathrm{ml} . / \mathrm{min} . / \mathrm{mm}$. Hg (mean $21 \cdot 2 \pm 4 \cdot 5$ ). The range of the ratio of $D_{L c J}$ body surface area for the control group was 8.8 to 17.8 and for the scleroderma patients from 1.6 to 15.9. Seven of the patients with scleroderma showed $D_{L c \text { s }}$ values below the lowest of the control

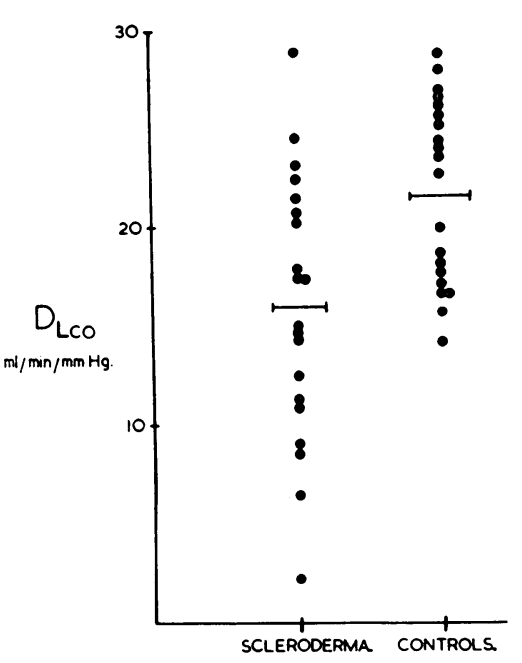

FIG. 3. Plot of $D_{\text {Lco }}$ in patients with scleroderma and $\mathrm{N}$ control subjects. The bars represent the means for cach $\mathrm{N}$ group.

group; five of these had a reduced V.C. and lung volumes.

Lung compliance was measured in 18 patients. The results ranged from 0.065 to 0.300 litre $/ \mathrm{cm}$. water (mean $0.137 \pm 0.067$ ) and from 0.107 to 0.360 litre $/ \mathrm{cm}$. water (mean $0.203 \pm 0.072$ ) in the $\frac{0}{\mathbb{D}}$ control group. Eight patients with scleroderma had compliance levels below those of the controls and $\stackrel{\varnothing}{\varnothing}$ below the lower limit of normal $(0 \cdot 100$ litre $/ \mathrm{cm}$. 


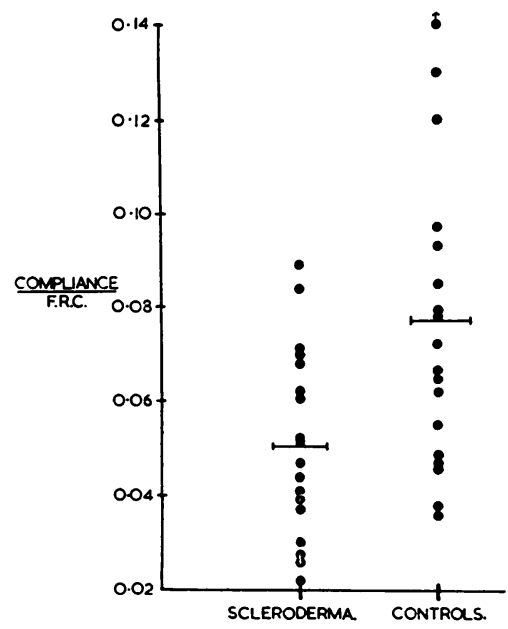

FIG. 4. Plot of ratio of $\frac{\text { compliance }}{\text { F.R.C. }}$ in scleroderma patients and control subjects. The bars represent the means for each group.

water) accepted by this laboratory. Figure 4 shows a plot of the ratio of compliance to F.R.C. Five patients had values below those of the control group and below the normal range for this ratio of 0.038 given by Marshall (1957). Three of the five also had a reduced V.C., but only one showed a defect in $\mathrm{DL}_{\mathrm{co}}$.

RELATION BETWEEN CLINICAL AND FUNCTIONAL ABNORMALITIES There was no direct relation between the duration of symptoms attributable to scleroderma and the degree of pulmonary involvement. Three of the seven patients with multiple abnormalities in pulmonary function (Nos. 5, 13, $14,18,20,21$, and 22) had symptoms extending over 10 years, and the remaining four (Nos. 18, 20,21 , and 22) had had symptoms for only five years or less. A complaint of shortness of breath did not imply severe impairment in pulmonary function nor an increased ventilatory response to exercise (Nos. 12, 16, and 18), although those with severe grades of exercise tolerance (grades IV and V) usually showed multiple functional abnormalities.

Localization of the skin changes to the fingers did not necessarily imply absence of severe pulmonary involvement (Nos. 3, 5, and 21). Similarly, there was no correlation between chest wall or oesophageal involvement and impaired pulmonary function. None of the seven patients with functional abnormality in several tests had lesions over the chest wall, and three had a normal barium swallow. Of the 12 patients with a chest expansion below $5 \mathrm{~cm}$., nine had a reduced vital capacity. The presence of basal crepitations did not necessarily imply severe impairment in pulmonary function, although the patients with crepitations over most of the chest (Nos. 20, 21, and 22) were severely affected. By contrast, the presence of abnormalities in the chest radiograph could be related to severe impairment of pulmonary function (Nos. $13,18,20,21$, and 22). Only one of four patients with systemic hypertension showed more than one abnormality in pulmonary function. The three patients with cardiographic evidence of pulmonary hypertension had multiple abnormalities with, in particular, a marked reduction in diffusing capacity; compliance was not measured in two.

In general, the seven patients with multiple defects in pulmonary function had the most severe impairment of exercise tolerance, basal crepitations, and abnormal chest radiographs, but there were notable exceptions. One patient (No. 14) claimed no impairment of exercise tolerance and had no basal crepitations, and two patients (Nos. 5 and 14) had normal chest radiographs.

HISTOLOGY Specimens of lung were examined in two subjects. One patient (No. 2) died after the rapid development of malignant hypertension with renal failure. Macroscopically, the pleural and cut surface of the lungs appeared normal. Microscopically (Fig. 5), cystic spaces, some of which were lined with bronchiolar epithelium, replaced the normal alveolar architecture. The interstitial tissue contained increased amounts of fibrous tissue. Patchy myocardial fibrosis with normal coronary vessels was an additional feature.

A lung biopsy (Fig. 6) in a second subject (No. 13) showed replacement of normal lung architecture by cysts lined with a columnar epithelium. The interstitial tissue showed a marked increase in smooth muscle, fibrous tissue, and hyaline material. Peribronchial giant cell systems with vacuolated cytoplasm were scattered throughout. Some pulmonary vessels showed proliferation of the media and intima but no evidence of fibrinoid necrosis.

\section{DISCUSSION}

The interpretation of correlations between the clinical features and the functional findings in the patients studied is of necessity limited to specific cases; generalizations based on the whole group are not only biased according to the selection of the patients in the series but also fail to reflect the variation in the clinical, radiological, electrocardiographic, and functional findings. 


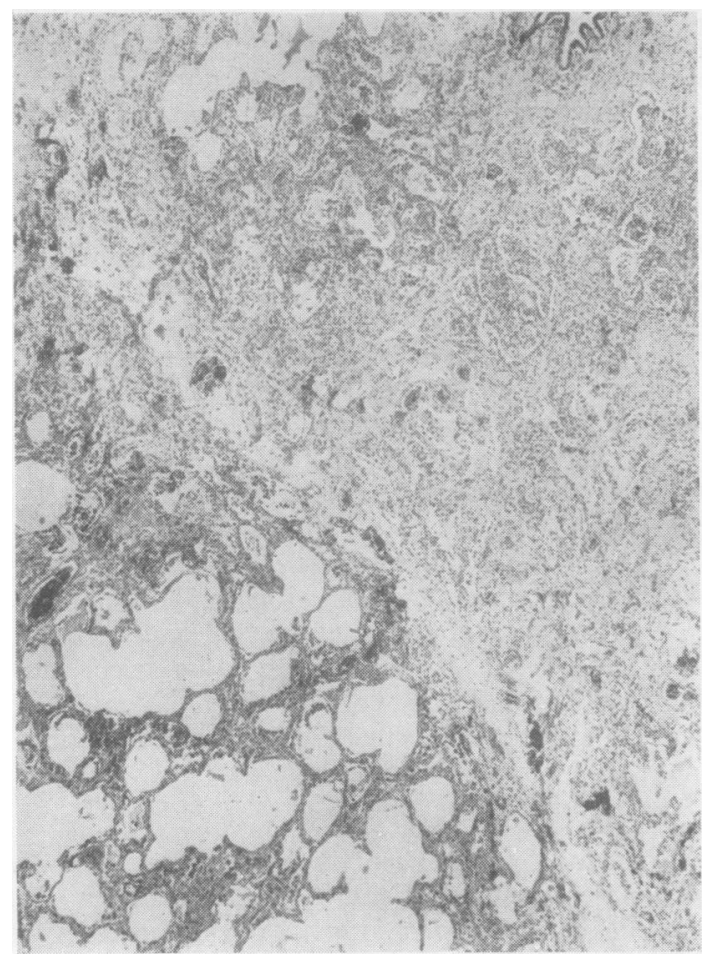

FIG. 5. Patient 2. Photomicrograph of necropsy specimen of lung showing reflacement of normal alveolar architecture by cystic spaces and compact areas of fibrous tissue. (Haematoxylin and eosin, $\times 50)$.

The variability of the respiratory symptoms paralleled the functional findings. The absence of shortness of breath in half of the patients studied did not necessarily imply normal lung function, a finding common to other diffuse lung diseases. The presence of chronic bronchitis in non-smokers, beginning after the onset of symptoms of scleroderma, suggests the possibility of bronchial involvement, as indicated by the pathological studies of Getzowa (1945) and of Talbott and Ferrandis (1956), who commented on fibrinoid changes in the bronchial mucosa. Similarly, the presence of bronchiectasis has been emphasized by Spain and Thomas (1950), but other workers (Hayman and Hunt, 1952 ; Murphy, Krainin, and Gerson, 1941) report bronchograms as being usually normal. Descriptions of pleural lesions in necropsied patients have not been infrequent (Getzowa, 1945 ; Orabona and Albano, 1958) but the rarity of symptoms of pleurisy emphasized by Opie (1955) has been notable. Four patients in this study gave a history of pleurisy but with no

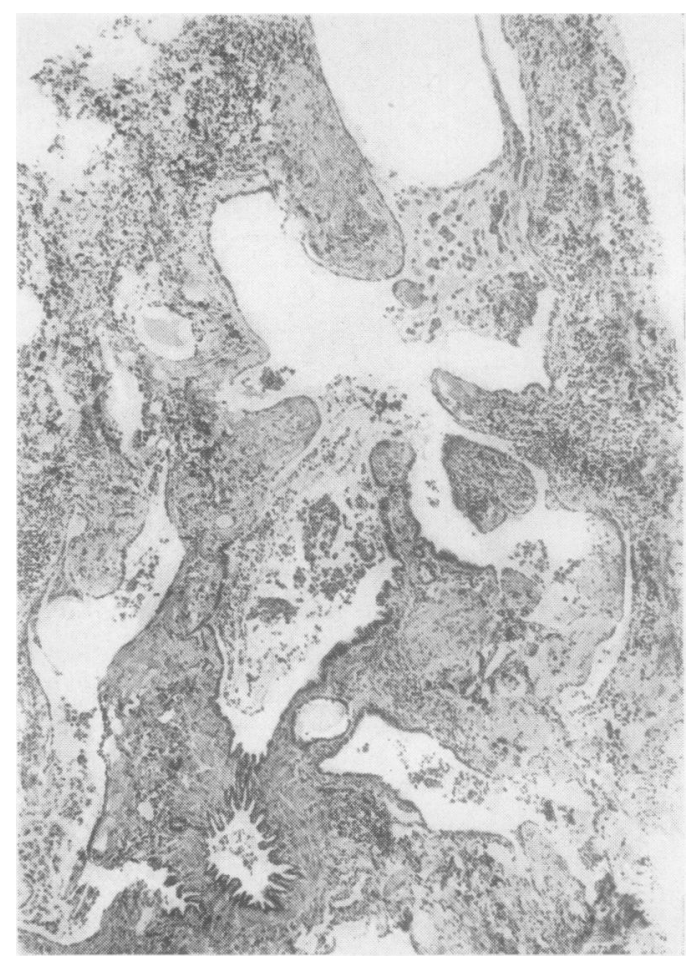

FIG. 6. Patient 13. Photomicrograph of lung biopsy $\overline{\bar{O}}$ showing cystic spaces lined with ciliated columnar epithelium and increased interstitial fibrous tissue and smooth muscle. (Haematoxylin and eosin, $\times 31$ ).

clinical or radiological evidence of residual abnormality.

The radiological appearances of pulmonary scleroderma have been classified by Garland and Sisson (1954) into (i) diffuse or localized fibrosis, (ii) diffuse or localized nodulation, (iii) subpleural 'cystic disease' (basal), and (iv) calcification. The $\subseteq$ earlier claim by Pugh (1948) that the appearances $\frac{T}{0}$ were diagnostic appears difficult to substantiate. In this study radiological abnormalities in the $N$ lungs were present in approximately a quarter of the series and the changes were not specific to $O$ scleroderma. Most of the patients with radio- $\omega$ graphic changes had severe defects in pulmonary function, suggesting that the radiograph detects only the more severe pathological changes.

Systemic hypertension was present in four patients and may have been related to scleroderma lesions in the kidney (confirmed by biopsy in one instance, No. 9). The presence of hypertensive left ventricular failure might simulate the clinical and functional aspects of scleroderma of the lung, 
but this does not explain the abnormalities in the present series. Recently Oram and Stokes (1961) have indicated the frequency of myocardial involvement in scleroderma. Of interest in this study were electrocardiographic findings of non-specific $T$ wave changes in one patient, radiological evidence of cardiac enlargement in another, and, in a third subject, patchy myocardial fibrosis at necropsy.

Pulmonary hypertension in scleroderma has been discussed by Opie (1955), who described its occurrence with minimal radiological abnormalities in the lung fields. The pathological studies of Matsui (1924) and of Weiss, Stead, Warren, and Bailey (1943), demonstrating the marked intimal proliferation of the pulmonary arterioles, point to vascular obstruction as probably the most significant factor in the rise of pressure. Sackner, Akgun, Kimbel, and Lewis (1962) note a high incidence of pulmonary hypertension in scleroderma and consider that this is not necessarily correlated with the clinical, radiological, or electrocardiographic signs. In the present study patients with clinical and electrocardiographic evidence of pulmonary hypertension all had gross functional defects with a low diffusing capacity, although the development of severe pulmonary hypertension with minimal radiological changes in the lung fields in one patient was notable.

Some authors (Finlay, 1889; Dinkler, 1891 ; Lewin and Heller, 1895) recorded the presence of respiratory symptoms and necropsy evidence of abnormal pulmonary fibrosis, but they attributed these changes to a reduction in mobility of the chest wall by the skin changes. The results of this study and those of others (Adhikari, Bianchi, Boushy, Sakamoto, and Lewis, 1962) indicate the lack of correlation between changes in the chest wall and impairment of pulmonary function. Harper (1953) related the pathological findings of fibrosis to 'spill over' from oesophageal stasis, but Mahrer, Evans, and Steinberg (1954) indicated the frequent absence of oesophageal changes in patients with pulmonary involvement. In this study only 13 of the 22 patients had evidence of oesophageal involvement, although most of the patients with severe impairment of pulmonary function had oesophageal lesions.

The results of pulmonary function studies in general confirm the finding of previous workers of a reduction in vital capacity, and its frequency stresses the usefulness of this measurement in patients with scleroderma. Evidence of mild airways obstruction in four patients suggested the possibility of bronchial involvement. The presence of an increased residual volume and functional residual capacity in two patients in the absence of airways obstruction supports similar observations by Salomon, Appel, Dougherty, Herschfus, and Segal (1955), although their findings were attributed to bronchial obstruction. The presence of ventilated cystic spaces in the absence of airways obstruction could explain these results but bronchographic (Hayman and Hunt, 1952) and pathological (Church and Ellis, 1950) evidence suggests that the cysts do not communicate directly with the bronchial tree.

A notable feature of the functional studies was the poor correlation between different tests, so that even in patients with severe defects all parameters of lung function were not necessarily affected. In patients with a single functional abnormality there was no one test consistently abnormal, although an increased ventilatory response to exercise was the most frequently found single defect. Wilson, Rodnan, and Robin (1962), and Catterall and Rowell (1963) suggested that a fall in diffusing capacity was possibly the earliest abnormality detectable, but this is not confirmed in the present study.

Classifications of scleroderma into local and general types based on the distribution of the cutaneous manifestations have received attention (Leading Article, 1961), and, in particular, skin changes localized to the fingers have been regarded by some authors (O'Leary and Waisman, 1943 ; Brunsting, 1959) as indicating a good prognosis. The present study suggests that neither the duration of the cutaneous symptoms nor the localization of the skin lesions allows prediction of the extent or severity of pulmonary involvement. It remains to be seen to what extent the accuracy of prognosis can be improved by the quantitative functional assessment of pulmonary involvement.

\section{SUMMARY}

A study of pulmonary function was made in 22 patients with scleroderma. Particular attention was paid to the relation between the clinical, radiographic, electrocardiographic, and functional findings. In general, a reduction in ventilatory capacity, lung volumes, compliance, and diffusing capacity with an increased ventilatory response to exercise was found, but individual variation in the functional defects was striking. The lack of correlation between the extent of the cutaneous lesions and the radiological changes in the lungs with functional impairment was a notable finding. There was no evidence that cutaneous lesions of the chest wall were responsible for the pulmonary changes. 
I am indebted particularly to Dr. F. H. Lumb for his invaluable assistance and to Dr. A. J. Barnett (Baker Institute) for permission to study the patients under his care. Thanks are due to Miss Nancy Rogers for technical assistance and to $\mathrm{Mr}$. K. Inglis for the photographic plates. I wish to thank Professor R. R. H. Lovell and Dr. Bryan Gandevia for their encouragement and helpful criticism.

\section{REFERENCES}

Adhikari, P. K., Bianchi, F. A., Boushy, S. F., Sakamoto, A., and Lewis, B. M. (1962). Pulmonary function in scleroderma. Amer. Rev. resp. Dis., 86, 823 .

Baldwin, E. deF., Cournand, A., and Richards, D. W., Jr. (1949). Pulmonary insufficiency: II. A study of 39 cases of pulmonary fibrosis. Medicine (Baltimore), 28, 1.

Brunsting, L. A. (1959). Scleroderma. Introduction and cutaneous aspects. In symposium on manifestations of scleroderma. Proc. Mayo Clin., 34, 53.

Catterall, M., and Rowell, N. R. (1963). Respiratory function in progressive systemic sclerosis. Thorax, 18, 10.

Church, R. E. and Ellis, A. R. P. (1950). Cystic pulmonary fibrosis in generalised scleroderma: report of two cases. Lancet, 1392.

Dinkler, M. (1891). Zur Lehre von der Sklerodermie. Dtsch. Arch. klin. Med., 48, 514.

Finlay, D. W. (1889). Scleroderma. Middlesex Hosp. Rep., p. 29.

Fletcher, C. M., and Tinker, C. M. (1961). Chronic bronchitis: A further study of simple diagnostic methods in a working population. Brit. med. J., 1, 1491 .

Gandevia, B. (1962).Pulmonary ventilation on exercise and the factors affecting a simple standardized exercise test. Amer. Rev. resp. Dis., 85, 378 .

Garland, L. H., and Sisson, M. A. (1954). Roentgen findings in the 'collagen' diseases. Amer. J. Roentgenol., 71, 581.

Getzowa, S. (1945). Cystic and compact pulmonary sclerosis in progressive scleroderma. Arch. Path. 40,99.

Harper, R. A. K. (1953). The radiological manifestations of diffuse systemic sclerosis (scleroderma). Proc. roy. Soc. Med., 46, 512.

Hayman, L. D., and Hunt, R. E. (1952). Pulmonary fibrosis in generalized scleroderma. Dis. Chest, 21,691

Leading Article (1961). Brit. med. J., 2, 1412.

Lewin, G., and Heller, J. (1895). Die Sclerodermie. Hirschwald, Berlin.

Mahrer, P. R., Evans, J. A., and Steinberg, I. (1954). Scleroderma: Relation of pulmonary changes to esophageal disease. Ann. intern. Med., 40,92.
Marshall, R. (1957). The physical properties of the lungs in relation to the subdivisions of lung volume. Clin. Sci., 16, 507 .

Matsui, S. (1924). Ưber die Pathologie und Pathogenese von Sclero- 음 dermia universalis. Mitt. med. Fak. Tokyo, 31, 55.

Miller, R. D., Fowler, W. S., and Helmholtz, F. H., Jr. (1959a). Scleroderma of the lungs. Proc. Mayo Clin., 34, 66.

Miller, W. F., Johnson, R. L., Jr., and Wu, N. (1959b). Relationships between fast vital capacity and various timed expiratory capa- 2

cities. J. appl. Physiol., 14, 157.
Murphy, J. R., Krainin, P., and Gerson, M. J. (1941). Scleroderma with pulmonary fibrosis. J. Amer. med. Ass., 116, 499.

Needham, C. D., Rogan, M. C., and McDonald, I. (1954). Normal $\vec{\odot}$ standards for lung volumes, intrapulmonary gas-mixing and maximum breathing capacity. Thorax, 9, 313 .

Ogilvie, C. M., Forster, R. E., Blakemore, W. S., and Morton, J. W. $\omega$ (1957). A standardized breath holding technique for the clinical measurement of the diffusing capacity of the lung for carbon monoxide. J. clin. Invest., 36, 1. O'Leary, P. A., and Waisman, M. (1943). Acrosclerosis. Arch. Derm.
Syph. (Chic.), 47, 382.

Opie, L. H. (1955). The pulmonary manifestations of generalized

scleroderma. Dis. Chest, 28, 665.
Orabona, M. L., and Albano, O.(1958). Progressive systemic sclerosis. i Acta med. scand., 160, Suppl. 333.

Oram, S., and Stokes, W. (1961). The heart in scleroderma. Brit. Heart 의 J., $23,243$.

Piper, W. N., and Helwig, E. B. (1955). Progressive systemic sclerosis ; visceral manifestations in generalized scleroderma. A.M.A. A r h h. C Derm., 72, 535 .

Pugh, D. G. (1948). Roentgenologic manifestations of scleroderma. Amer, J med Sci, 216, 571.

Sackner, M. A., Akgun, N., Kimbel, P., and Lewis, D. H. (1962). Pulmonary hypertension; a surprisingly common finding in scleroderma. Clin. Res., 10, 242.

Salomon, A., Appel, B., Dougherty, E. F., Herschfus, J. A.. and Segal, M. S. (1955). Scleroderma; pulmonary and skin studies $\triangle$ before and after treatment with cortisone. A.M.A. Arch. intern Med., 95, 103

Shuford, W. H., Seaman, W. B., and Goldman, A. (1953). Pulmonary manifestations of scleroderma. Ibid., 92,85 .

Spain, D. M., and Thomas, A. G. (1950). The pulmonary manifesta tions of scleroderma; an anatomic physiological correlation. Ann. intern. Med., 32, 152.

Talbott, J. H., and Ferrandis, R. M. (1956). Collagen Diseases. 을 Grune and Stratton, New York.

Weiss, S., Stead, E. A., Warren, J. V., and Bailey, O. T. (1943). Scleroderma heart disease, with a consideration of certain other $\overline{\vec{O}}$ visceral manifestations of scleroderma. Arch intern. Med. 71, 749.

Wilson, R. J., Rodnan, G. P., and Robin, E. D. (1962). Án early pulmonary physiologic abnormality in progressive systemic sclerosis (diffuse scleroderma). Clin. Res., 10, 244. 